\title{
Modeling Water Flow and Phosphorus Sorption in a Soil Amended with Sewage Sludge and Olive Pomace as Compost or Biochar
}

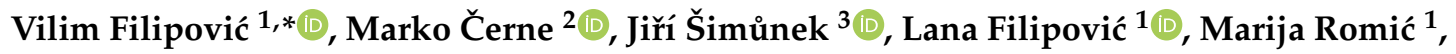 \\ Gabrijel Ondrašek ${ }^{1}$ (), Igor Bogunović ${ }^{1}{ }^{\circledR}$, Ivan Mustać ${ }^{1}$, Vedran Krevh ${ }^{1}$, Anja Ferenčević ${ }^{1}$, \\ David Robinson ${ }^{4}$, Igor Palčić ${ }^{2}{ }^{\circledR}$, Igor Pasković ${ }^{2}{ }^{\oplus}$, Smiljana Goreta Ban ${ }^{2}{ }^{\circledR}$, Zoran Užila ${ }^{2}$ and \\ Dean Ban ${ }^{2}$ \\ 1 Faculty of Agriculture, University of Zagreb, Svetošimunska 25, 10000 Zagreb, Croatia; \\ lfilipovic@agr.hr (L.F.); mromic@agr.hr (M.R.); gondrasek@agr.hr (G.O.); ibogunovic@agr.hr (I.B.); \\ imustac@agr.hr (I.M.); vkrevh@agr.hr (V.K.); anjaferencevic7@gmail.com (A.F.) \\ 2 Institute of Agriculture and Tourism, Karla Huguesa 8, 52440 Poreč, Croatia; marko@iptpo.hr (M.Č.); \\ palcic@iptpo.hr (I.P.); paskovic@iptpo.hr (I.P.); smilja@iptpo.hr (S.G.B.); zoran@iptpo.hr (Z.U.); \\ dean@iptpo.hr (D.B.) \\ 3 Department of Environmental Sciences, University of California Riverside, Riverside, CA 92521, USA; \\ jiri.simunek@ucr.edu \\ 4 UK Centre for Ecology \& Hydrology, ECW, Bangor LL57 2UW, UK; davi2@ceh.ac.uk \\ * Correspondence: vfilipovic@agr.hr; Tel.: +385-1-239-3711
}

Received: 15 July 2020; Accepted: 6 August 2020; Published: 8 August 2020

\begin{abstract}
Organic amendments are often reported to improve soil properties, promote plant growth, and improve crop yield. This study aimed to investigate the effects of the biochar and compost produced from sewage sludge and olive pomace on soil hydraulic properties, water flow, and $\mathrm{P}$ transport (i.e., sorption) using numerical modeling (HYDRUS-1D) applied to two soil types (Terra Rosa and Rendzina). Evaporation and leaching experiments on soil cores and repacked soil columns were performed to determine the soil water retention, hydraulic conductivity, P leaching potential, and P sorption capacity of these mixtures. In the majority of treatments, the soil water retention showed a small increase compared to the control soil. A reliable fit with the modified van Genuchten model was found, which was also confirmed by water flow modeling of leaching experiments $\left(R^{2} 0.99\right)$. The results showed a high $\mathrm{P}$ sorption in all the treatments $\left(K_{d} 21.24\right.$ to $\left.53.68 \mathrm{~cm}^{3} \mathrm{~g}^{-1}\right)$, and a high model reliability when the inverse modeling procedure was used $\left(R^{2}\right.$ 0.93-0.99). Overall, adding sewage sludge or olive pomace as compost or biochar improved the Terra Rosa and Rendzina water retention and did not increase the P mobility in these soils, proving to be a sustainable source of carbon and P-rich materials.
\end{abstract}

Keywords: soil amendments; inverse estimation; numerical modeling; phosphate; HYDRUS

\section{Introduction}

The application of biochars or composts to soil may improve soil properties, promote plant growth, or have a positive effect on crop yield [1-4]. Biochar is a pyrogenic carbon derived from carbon-rich waste materials, primarily agricultural residuals [5,6]. It is uncertain how it will impact soil physical properties, as its properties often vary [7] depending on the means of production, especially temperature [8]. Compost can alter soil physicochemical properties and promote plant growth [9]. Producing biochars or composts from different organic materials is also an effective way to reduce agricultural biomass waste while recycling and sterilizing it. Substantial amounts of waste are produced annually worldwide, 
including agricultural residues, sewage sludge, and municipal solid waste, all of which can provide an important supply of raw materials for recycling as biochar or compost. China and the USA are estimated to produce $\sim 1.4$ billion Mtons of annual agricultural biomass waste, which has the potential to produce $\sim 420$ million Mtons of biochar or compost per year [10,11]. Compost and biochar are commonly applied to soil to improve the quality of the so-called "problem soils" [12]. Both biochar and compost soil amendments are usually applied to the soil under the guidance of safety regulations to avoid possible harmful effects on soil, vegetation, animals, and humans [13].

The application of soil organic amendments is known to alter soil physical properties, for example by reducing the bulk density, increasing the infiltration rate and hydraulic conductivity, increasing the water retention, and enhancing the aggregate stability $[4,11,14]$. In turn, this supports improvements in plant growth [10,15]. Villagra-Mendoza and Horn [16] studied the effects of wood-based biochar on two soils with different textures and their hydrological properties, such as water retention, shrinkage behavior, and hydraulic conductivity. The biochar amendments tested were found to increase the soil water retention in coarse-textured sand compared to unamended soil. The pore size distribution of the sandy substrate was also significantly altered by reducing the fraction of large coarse pores while increasing the mesoporosity. Repeated soil wetting and drying cycles enhanced the structural stability of the pore system while increasing the saturated hydraulic conductivity. A similar study was conducted by Mohawesh and Durner [17], who tested the effects of hydrogel (Luquasorb hydrogel, BASF SE Company, Germany), bentonite (smectite clay), and biochar as soil amendments on soil hydraulic properties. The results revealed that the control soil retained less water at any matric potential compared to the amended soils. However, the soil hydraulic conductivity also decreased with an increase in these soil amendments.

Various elements, including nutrients, are present in soil amendments, depending on the type and origin of waste from which they are produced. Phosphorus $(\mathrm{P})$, a macronutrient required for optimal plant growth [18], often needs to be added to agricultural soils in a fertilizer form. It is frequently present in various soil amendments and needs to be recycled, as it cannot be synthesized and is currently mined from finite sources [19]. Three factors largely control $\mathrm{P}$ availability: the $\mathrm{pH}$ and mineralogy, organic matter levels, and fertilizer additions. P deficiency may occur due to acid or alkali conditions (pH 6-7 is optimal), or due to a naturally slow release from mineral inorganic P. Adding inorganic or organic $\mathrm{P}$ as a fertilizer to arable soils with $\mathrm{P}$ deficiency, or simply to replenish the $\mathrm{P}$ removed by crops, helps maintain productivity. However, $\mathrm{P}$ leaching or $\mathrm{P}$ removal by soil erosion from heavily fertilized agricultural lands leads to aquatic pollution. The increased concentration of phosphorus in aquatic ecosystems is one of the main causes of water eutrophication [20]. Incorporating P-rich organic amendments, such as compost or biochar, can possibly reduce or prevent negative environmental effects caused by $P$ leaching while ensuring optimal conditions for crop growth due to amendments to the sorption properties.

Numerical models use different mathematical and numerical approaches, which can simulate a variety of vadose zone processes, including the leaching and sorption of $\mathrm{P}$ throughout the soil profile. For example, Morrison et al. [21] first used the DRAINMOD model to simulate soil water flow in the field. They then performed a linear regression analysis, according to water flow, to predict the $P$ loss. Van der Salm et al. [22] used the PLEASE model to simulate the P losses from soils in Denmark and the Netherlands based on the P concentrations in tile drains, suction cups, and groundwater. Larsson et al. [23] used the dual-porosity ICECREAM model to simulate the P losses in tile drainage from clay soil. The HYDRUS code is also widely used for modeling water and solute dynamics in the (un)saturated soil zone in one, two, or three dimensions [24]. Kadyampakeni et al. [25] used HYDRUS-1D to predict the temporal movement of $P$ in two soil types using the laboratory-derived sorption coefficient $\left(K_{d}\right)$. Ben-Gal and Dudley [26] used HYDRUS-2D for analyzing data from a greenhouse study of the effects of continuous and intermittent drip irrigation regimes on the water movement and $\mathrm{P}$ distribution in soil monolith lysimeters. Their results showed that a high-frequency or continuous low-volume irrigation could maintain uniform distribution patterns of water and $\mathrm{P}$ 
and improve the conditions for plant growth and water and nutrient uptake. Although the simulated and measured P concentrations (soluble vs. bicarbonate-extractable P) were not directly comparable, the observed differences were explained by the variability in the soil parameters, preferential flow, and the use of the Langmuir sorption kinetic model. On the other hand, Elmi et al. [27], in their study of phosphate $\left(\mathrm{PO}_{4}\right)$ vertical distribution and transport processes in reconstructed soil columns, described sorption kinetics using the Freundlich equation. The model overpredicted the $\mathrm{PO}_{4}$ sorption, which was explained by preferential flow and difficulty in quantifying nonlinear reaction types. HYDRUS (its 3D version) was also used in the study of Naseri et al. [28], who assessed the effects of different water flux densities on the $\mathrm{P}$ transport in soil columns. While the soil water content was successfully reproduced, the linear sorption kinetics still overestimated the final adsorbed $\mathrm{PO}_{4}$ concentrations.

One way to obtain a better description of experimental data is to inversely reproduce sorption kinetics using the final $\mathrm{P}$ concentrations, additionally avoiding overestimation by the model. Using the inverse modeling approach, the unknown soil hydraulic or solute transport and reaction parameters can be estimated or further optimized by minimizing deviations between the observed and model-simulated variables (e.g., concentrations, water contents, fluxes) collected during leaching experiments [29]. This approach allows the estimation of parameters which are difficult or even impossible to measure directly. The inverse parameter optimization approach is commonly used for the estimation of soil hydraulic [30,31] or solute transport and reaction (e.g., sorption) parameters [32].

Organic amendments can significantly improve crop production while, at the same time, decreasing the amount of organic waste. However, ensuring we do not swap the problem of waste for the problem of pollution is important. Therefore, studies focused on understanding the main soil properties and processes affected by the amendment application are important, especially when evaluated from an agricultural and environmental perspective for decision-making. For example, when applying amendments to agricultural soil, it is important to estimate the soil water flow and element sorption kinetics [33,34], as these processes will determine its agricultural significance and the environmental impact.

The aim of this study was, therefore, to investigate the effects of biochar and compost produced from sewage sludge and olive pomace on soil hydraulic properties, water flow, and P transport (i.e., sorption) using numerical modeling (HYDRUS-1D). The objectives were threefold:

i. Conduct a controlled set of column experiments on two common agricultural soils to determine how two amendments (biochar and compost) from two waste sources (sewage sludge and olive pomace) applied at two concentrations (a guideline rate and $(10 \times)$ higher) affect soil hydraulic properties and P sorption and mobility;

ii. Simulate water flow and use inverse modelling to estimate the P sorption coefficient $\left(K_{d}\right)$ in each treatment;

iii. Analyze the results to determine how the amendments impact the soil hydraulic functions and P mobility.

\section{Materials and Methods}

\subsection{Soil Types and Amendments}

The Terra Rossa and Rendzina soils (Cambisol Rhodic and Leptosol Calcaric, according to IUSS WRB (2015) [35] used in the experiment were collected from topsoil (0-30 cm depth) at selected sites from the Istrian peninsula, Croatia. These two soil types (Terra Rossa and Rendzina) were selected because of their contrasting organic $\mathrm{C}(0.7 \%$ and $6.1 \%)$ and $\mathrm{P}$ contents $\left(350.2\right.$ and $\left.301.8 \mathrm{mg} \mathrm{kg}^{-1}\right)$ and their similar $\mathrm{pH}$ (6.55 and 7.69). The Terra Rosa had a texture of $7 \%$ sand, $57 \%$ silt, and $36 \%$ clay, while Rendzina had a texture of 3\% sand, $50 \%$ silt, and $47 \%$ clay. Furthermore, the municipal dewatered and aerobically stabilized sewage sludge (SS) was obtained from the local wastewater treatment facility. At the same time, the olive pomace (OP) produced using a two-phase extraction system was obtained from a local olive mill facility. These were used as raw materials to produce compost and biochar 
amendments. Additional information regarding the soil properties and the properties of SS and OP (chemical and physical properties with processing information presented) are explained in detail in Černe et al. [36] and in the Supplementary Material.

The Compost Sewage Sludge (CSS) and Compost Olive Pomace (COP) were produced at the experimental farm of the Institute of Agriculture and Tourism, Croatia. For composting, an enclosure with inner dimensions of $77 \times 77 \times 77 \mathrm{~cm}$ constructed from concrete blocks was used. The composting mixture consisted of aerobic SS and wheat straw at a ratio of $40 \mathrm{~kg}$ of straw per $1 \mathrm{~m}^{-3}$ of SS to adjust the $\mathrm{C} / \mathrm{N}$ ratio. The OP was composted without any additional material. For efficient aerobic degradation, standard agricultural measures were applied [37]. For instance, the temperature was monitored daily in the center of a pile using temperature sensors (ONSET HOBO series). The relative humidity (RH) was maintained at between $55 \%$ and $60 \%$ and controlled according to EPA (2001) [38]. Aeration was performed monthly by turning the pile by hand. After three months, the compost maturity and quality were evaluated according to Canet et al. [37].

The Biochar Sewage Sludge (BSS) and Biochar Olive Pomace (BOP) were produced using a system following the Kon-Tiki model [39]. An amount of $30 \mathrm{~L}$ of SS and OP material was combusted during one pyrolytic cycle, which lasted approximately $3 \mathrm{~h}$. To monitor the pyrolysis process, the temperature was measured using a NiCrNi thermoelement and ranged from 410 to $470{ }^{\circ} \mathrm{C}$. At the end of the pyrolytic cycle, the process was stopped using water quenching. More details regarding the chemical properties and processing information of the soil amendments can be found in Černe et al. [36] and in the Supplementary Material. The trace metals and macro- and microelements were determined by inductively coupled plasma-optical emission spectrometry, ICP-OES (Vista-MPX, Varian, Inc., Palo Alto, CA, USA), after microwave digestion according to HRN ISO 22036:2011. The soil $\mathrm{pH}$ and electrical conductivity (EC) were measured using the Mettler Toledo MPC 227 conductivity/pH-meter in water ( $\mathrm{pH} \mathrm{H}_{2} \mathrm{O}$ ) (HRN ISO 10390:2005), while the organic $\mathrm{C}$ content was determined using sulfochromic oxidation (HRN ISO 14235:1998), and N concentration according to the adapted Kjeldahl method (HRN ISO 11261:2004).

\subsection{Experimental Set-Up}

A column study was conducted in a greenhouse of the Institute of Agriculture and Tourism, Poreč, Croatia. The compost (CSS and COP) and biochar (BSS and BOP) were sieved ( $2 \mathrm{~mm}$ ) to assure their homogeneous distribution in the soil-amendment mixture. The amendments were added at rates calculated on a P content basis; $(\mathrm{P})$ according to the Croatian legislation on sewage sludge agricultural use, the NN 38/08 (i.e., $12 \mathrm{mg} \mathrm{P} \mathrm{L}^{-1}$ ) and $(\mathrm{P}+) 10$ times higher rate than recommended by the Croatian legislation (i.e., $\left.120 \mathrm{mg} \mathrm{P} \mathrm{L}^{-1}\right)$. On September 13th, 2017, repacked soil columns $(20 \mathrm{~cm}$ diameter $\times 20 \mathrm{~cm}$ height) were filled with soil (Terra Rossa or Rendzina) amended with (a) compost sewage sludge (CSS), (b) biochar sewage sludge (BSS), (c) compost olive pomace (COP), and (d) biochar olive pomace (BOP), with each at the $\mathrm{P}$ and $\mathrm{P}+$ application rates. Terra Rossa or Rendzina control soils were also used in the experiment as non-modified soils (_0) and control soils with added phosphorus (_P) at concentration levels recommended by the Croatian legislation (i.e., $12 \mathrm{mg} \mathrm{P} \mathrm{L}^{-1}$ ).

The columns were prepared in four replicates to reduce the effects of unknown systematic bias. A four-factor experimental column design was used: two soils-Terra Rossa (T) and Rendzina (R); two organic materials—sewage sludge (SS) and olive pomace (OP); two soil amendments-compost (C) and biochar (B) - applied at two amendment application rates (P and $\mathrm{P}+$ ); and two controls for each soil type (_0 and _P). A total of 16 treatments and four controls were used (Tables 1 and 2 ). 
Table 1. Description of treatments from a greenhouse pot experiment with the Terra Rosa (T) soil amended with biochar (B) or compost (C) produced from sewage sludge (SS) or olive pomace (OP) at two application rates calculated on a $\mathrm{P}$ content basis (according to legislation, $\mathrm{P}$; and a 10 times higher rate, $\mathrm{P}+)$.

\begin{tabular}{|c|c|c|c|c|}
\hline Treatment Abbreviation & Soil & Treatment Method & Waste Type & P-Level \\
\hline TBSS_P & Terra Rossa & biochar & sewage sludge & P-regulation \\
\hline TBSS_P+ & Terra Rossa & biochar & sewage sludge & P-10 $\times$ higher \\
\hline TBOP_P & Terra Rossa & biochar & olive pomace & P-regulation \\
\hline TBOP_P+ & Terra Rossa & biochar & olive pomace & P-10 $\times$ higher \\
\hline TCSS_P & Terra Rossa & compost & sewage sludge & P-regulation \\
\hline TCSS_P+ & Terra Rossa & compost & sewage sludge & P-10 $\times$ higher \\
\hline TCOP_P & Terra Rossa & compost & olive pomace & P-regulation \\
\hline TCOP_P & Terra Rossa & compost & olive pomace & P-10 $\times$ higher \\
\hline T_P & Terra Rossa & l & 1 & P-regulation \\
\hline T_0 & Terra Rossa & / & / & 0 \\
\hline
\end{tabular}

Table 2. Description of treatments from a greenhouse pot experiment with the Rendzina (R) soil amended with biochar (B) or compost (C) produced from sewage sludge (SS) or olive pomace (OP) at two application rates calculated on a $\mathrm{P}$ content basis (according to legislation, $\mathrm{P}$; and a 10 times higher rate, $\mathrm{P}+)$.

\begin{tabular}{|c|c|c|c|c|}
\hline Treatment Abbreviation & Soil & Treatment Method & Waste Type & P-Level \\
\hline RBSS_P & Rendzina & biochar & sewage sludge & P-regulation \\
\hline RBSS_P+ & Rendzina & biochar & sewage sludge & P-10 $\times$ higher \\
\hline RBOP_P & Rendzina & biochar & olive pomace & P-regulation \\
\hline RBOP_P+ & Rendzina & biochar & olive pomace & P-10 $\times$ higher \\
\hline RCSS_P & Rendzina & compost & sewage sludge & P-regulation \\
\hline RCSS_P+ & Rendzina & compost & sewage sludge & P-10 $\times$ higher \\
\hline RCOP_P & Rendzina & compost & olive pomace & P-regulation \\
\hline RCOP_P & Rendzina & compost & olive pomace & P-10 $\times$ higher \\
\hline R_P & Rendzina & / & 1 & P-regulation \\
\hline R_0 & Rendzina & l & / & 0 \\
\hline
\end{tabular}

\subsection{Column Leaching Experiment and Chemical Analysis}

During the experiment, the night temperatures ranged from 8 to $12{ }^{\circ} \mathrm{C}$, and the daytime temperatures ranged from 15 to $25^{\circ} \mathrm{C}$, while the relative humidity varied between $35 \%$ and $70 \%$. The columns were irrigated with tap water using a handheld sprayer to maintain the amended soil water content at near $75 \%$ of the water-holding capacity. Before the leaching experiments, the columns were saturated and left to drain excess water to reach steady-state (matching) conditions to achieve the same initial conditions. At the beginning of the experiment, soil samples were taken (from all 16 treatment columns and 4 control columns) for the determination of the total P concentration in the soil using the aqua regia extraction method, and measured using optical emission spectrometry-inductively coupled plasma (Vista MPX AX, Varian). For the leaching experiment, the columns were irrigated three times with $500 \mathrm{~mL}$ of water at each irrigation event during one week. The leaching experiment was conducted on columns without the crop for the purpose of evaluating the P mobility when no crop is present in the field. The leachate was collected from the columns after each irrigation event, and its volume was measured. The leachate samples were transported to the laboratory where they were stored under low-temperature conditions $\left(4^{\circ} \mathrm{C}\right)$ until the orthophosphates $\left(\mathrm{PO}_{4}-\mathrm{P}\right)$ were analyzed using a continuous flow auto-analyzer (San++ Continuous Flow Analyzer, Skalar). The leaching experiment and soil (treatments) total P results are presented in Table 3. 
Table 3. Total phosphorus concentration in the soil before the leaching experiment, and the volumes of irrigation water added in columns filled with the Terra Rosa (T) or Rendzina (R) soils amended with biochar (B) or compost (C) produced from sewage sludge (SS) or olive pomace (OP) at two application rates, calculated on a P content basis (according to legislation, $\mathrm{P}$; and a 10 times higher rate, $\mathrm{P}+)(n=4)$.

\begin{tabular}{|c|c|c|c|c|c|}
\hline $\begin{array}{c}\text { Treatment } \\
\text { Abbreviation }\end{array}$ & $\begin{array}{c}\text { Total P } \\
\text { Concentration in } \\
\text { Soil }\left(\mathrm{mg} \mathrm{kg}^{-1}\right)\end{array}$ & $\begin{array}{c}\text { Irrigation } \\
\text { Volume (mL) }\end{array}$ & $\begin{array}{c}\text { Treatment } \\
\text { Abbreviation }\end{array}$ & $\begin{array}{c}\text { Total P } \\
\text { Concentration in } \\
\text { Soil }\left(\mathrm{mg} \mathrm{kg}^{-1}\right)\end{array}$ & $\begin{array}{c}\text { Irrigation } \\
\text { Volume (mL) }\end{array}$ \\
\hline TBSS_P & 323.2 & $500(3 \times)$ & RBSS_P & 270.4 & $500(3 \times)$ \\
\hline TBSS_P+ & 474.1 & $500(3 \times)$ & RBSS_P+ & 366.9 & $500(3 \times)$ \\
\hline TBOP_P & 308.4 & $500(3 \times)$ & RBOP_P & 249.8 & $500(3 \times)$ \\
\hline TBOP_P+ & 317.7 & $500(3 \times)$ & RBOP_P+ & 258.9 & $500(3 \times)$ \\
\hline TCSS_P & 312.8 & $500(3 \times)$ & RCSS_P & 254.8 & $500(3 \times)$ \\
\hline TCSS_P+ & 350.9 & $500(3 \times)$ & RCSS_P+ & 294.4 & $500(3 \times)$ \\
\hline TCOP_P & 313.1 & $500(3 \times)$ & RCOP_P & 247.7 & $500(3 \times)$ \\
\hline TCOP_P+ & 358.7 & $500(3 \times)$ & RCOP_P+ & 333.2 & $500(3 \times)$ \\
\hline T_P & 422.8 & $500(3 \times)$ & R_P & 490.5 & $500(3 \times)$ \\
\hline T_0 & 320.6 & $500(3 \times)$ & R_0 & 251.5 & $500(3 \times)$ \\
\hline
\end{tabular}

\subsection{Soil Hydraulic Parameters Estimation}

The soil physical properties were measured for each treatment and control separately, first for the unamended soil, and then again after the biochar/compost addition. The particle size distribution was determined using a combination of sieving and sedimentation analysis from bare soil (Terra Rosa and Rendzina) according to Gee and Or [40]. The soil hydraulic properties were determined on undisturbed soil cores of $250 \mathrm{~cm}^{3}$ volume ( $n=2$ per treatment) by pushing the rings into the columns (for all 16 treatments and 4 controls). The soil hydraulic properties were estimated using the extended evaporation method [41]. The undisturbed soil samples $\left(250 \mathrm{~cm}^{3}\right)$ were saturated from the bottom and allowed to drain, then sealed at the bottom. Two tensiometers were inserted into each soil sample at depths of 1.5 and $4.6 \mathrm{~cm}$. The tensiometers (5.0 and $2.5 \mathrm{~cm}$ in length) were inserted in the upward direction to minimize the amount of water draining from the tensiometers into the soil during the experimental stage. The experiments were started by removing the upper cap of the soil samples to expose the soil surface to evaporation. The overall mass and pressure heads were recorded every 30 min using the HYPROP system (METER Group, Inc., Pullman, WA 99163, USA). The experiments continued until the measurement limit of about $-800 \mathrm{~cm}$ of the upper tensiometer was reached. An additional point of the air-entry pressure of the tensiometer's porous ceramic cup was used for the quantification of hydraulic functions close to the wilting point, which extended the measurement range of the evaporation method [41].

The modified analytical model of van Genuchten (the VC model [42]), describing the unsaturated soil hydraulic functions (i.e., the soil water retention curve and the unsaturated hydraulic conductivity function), was used for the modeling. The model was used to add flexibility to the description of the hydraulic conductivity near saturation. The soil water retention, $\theta(h)$, and hydraulic conductivity, $K(h)$, functions are then given by:

$$
\begin{gathered}
\theta(h)=\left\{\begin{array}{cc}
\theta_{r}+\frac{\theta_{s}-\theta_{r}}{\left(1+|\alpha h|^{n}\right)^{m}} & h<0 \\
\theta_{s} & h \geq 0
\end{array},\right. \\
K(h)=\left\{\begin{array}{cc}
K_{s} K_{r}(h) & h \leq h_{k} \\
K_{k}+\frac{\left(h-h_{k}\right)\left(K_{s}-K_{k}\right)}{h_{s}-h_{k}} & h_{k}<h<h_{s} \\
K_{s} & h \geq h_{s}
\end{array},\right.
\end{gathered}
$$




$$
\begin{gathered}
K_{r}=\frac{K_{k}}{K_{s}}\left(\frac{S_{e}}{S_{e k}}\right)\left[\frac{F\left(\theta_{r}\right)-F(\theta)}{F\left(\theta_{r}\right)-F\left(\theta_{k r}\right)}\right]^{2}, \\
F(\theta)=\left[1-\left(\frac{\theta-\theta_{r}}{\theta_{s}-\theta_{r}}\right)^{1 / m}\right]^{m}, \\
S_{e k}=\frac{\theta_{k}-\theta_{r}}{\theta_{s-} \theta_{r}},
\end{gathered}
$$

where $\theta(h)$ and $K(h)$ are the volumetric water contents $\left[\mathrm{L}^{3} \mathrm{~L}^{-3}\right]$ and unsaturated hydraulic conductivities $\left[\mathrm{L} \mathrm{T}^{-1}\right]$ at the soil water pressure heads $h[\mathrm{~L}]$, respectively; $\theta_{r}$ and $\theta_{s}$ denote the residual and saturated soil water contents $\left[\mathrm{L}^{3} \mathrm{~L}^{-3}\right]$, respectively; $S_{e}$ is the effective saturation; $K_{s}$ is the saturated hydraulic conductivity $\left[\mathrm{L} \mathrm{T}^{-1}\right] ; \alpha$ is the inverse of air-entry value or bubbling pressure $\left[\mathrm{L}^{-1}\right] ; n$ is the pore size distribution index [-]; and $l$ is the pore connectivity parameter [-]. The above Equation (2) assumes that the predicted hydraulic conductivity function is matched to a measured value of the hydraulic conductivity, $K_{k}=K\left(\theta_{k}\right)$, at a particular water content, $\theta_{k}$, less than or equal to the saturated water content-i.e., $\theta_{k} \leq \theta_{s}$ and $K_{k} \leq K_{s}[42,43]$. The $S_{e k}$ is the effective saturation at $\theta_{k}$. This model allows using the evaporation data for the soil matrix and extension of the $K(h)$ function to independently determine $K_{s}$ using a linear transition. The $K_{s}$ rate was initially calculated based on the collected outflow from the leaching experiment. The residual water content $\theta_{r}$ was set to 0 , as it was previously found not to affect the soil water retention curve $[44,45]$.

\subsection{Numerical Modeling of Water Flow and P Transport}

Numerical modeling was performed using the HYDRUS-1D program [46]. The water flow simulations in a one-dimensional soil profile were based on the numerical solution of the Richards equation for variably saturated porous media:

$$
\frac{\partial \theta(h)}{\partial t}=\frac{\partial}{\partial z}\left[K(h) \frac{\partial h}{\partial z}+1\right]
$$

where $\theta$ is the volumetric water content $\left[\mathrm{L}^{3} \mathrm{~L}^{-3}\right], h$ is the water pressure head $[\mathrm{L}], t$ is the time $[\mathrm{T}], z$ is the spatial coordinate [L] (positive upward), and $K$ is the hydraulic conductivity $\left[\mathrm{LT}^{-1}\right]$.

Solute transport $\left(\mathrm{PO}_{4}-\mathrm{P}\right)$ was described using the Fickian-based advection-dispersion equation:

$$
\frac{\partial \theta}{\partial t}+\frac{\partial(\rho s)}{\partial t}=\frac{\partial}{\partial z}\left(\theta D \frac{\partial c}{\partial z}-q c\right)-\varnothing
$$

where $c$ is the solute concentration in the liquid phase $\left[\mathrm{M} \mathrm{L}^{-3}\right] ; q$ represents the volumetric water flux density $\left[\mathrm{L} \mathrm{T}^{-1}\right] ; \rho$ is the bulk density of the soil $\left[\mathrm{M} \mathrm{L}^{-3}\right] ; s$ is the adsorbed concentration $\left[\mathrm{M} \mathrm{M}^{-1}\right]$; $\varnothing$ is the rate of change of the solute mass per unit volume of soil by chemical or biological reactions or other sources (negative) or sinks (positive) $\left[\mathrm{M} \mathrm{L}^{-3} \mathrm{~T}^{-1}\right]$; and $D$ is the dispersion coefficient $\left[\mathrm{L}^{2} \mathrm{~T}^{-1}\right]$, which is defined as follows:

$$
\theta D=D_{L}|q|+\theta D_{m} \tau,
$$

where $D_{m}$ is the coefficient of molecular diffusion $\left[\mathrm{M} \mathrm{L}^{2} \mathrm{~T}^{-1}\right], \tau$ is the tortuosity factor [-], and $D_{L}$ represents the longitudinal dispersivity [L].

The phosphorus sorption to soil particles was simulated considering equilibrium linear adsorption (Equation (9)), which describes the relationship between the sorbed and liquid phase concentrations:

$$
s=K_{d} c
$$

where $K_{d}\left[\mathrm{~L}^{3} \mathrm{M}^{-1}\right]$ is the $\mathrm{P}$ distribution (sorption) coefficient.

The initial conditions for the water flow modeling were set to the pressure head of 0 at the bottom and $-20 \mathrm{~cm}$ at the top (hydrostatic equilibrium) of the soil column to match the experimental conditions. 
A time-variable atmospheric flux boundary condition (applied irrigation and evaporation) was used at the top, and a seepage face boundary condition was applied at the bottom of the column.

Phosphorus can exist in the soil in various chemical forms [47,48], all of which cannot be taken into consideration by the model, so the reaction model used for the simulation of P sorption is based on a simplified P soil chemistry. As bidirectional transformations of multiple solutes cannot be simulated using the conventional advection-dispersion equation solved by HYDRUS (or any known mechanistic model), the numerical analysis focused instead on the dissolved P (orthophosphate, $\mathrm{PO}_{4}-\mathrm{P}$ ). Orthophosphate present in the soil solution is desorbed, and therefore available and leachable as a soil $\mathrm{P}$ fraction. Thus, $\mathrm{PO}_{4}-\mathrm{P}$ was selected for the numerical analysis due to its water-soluble nature, its presence in soil solution at near-neutral $\mathrm{pH}$, and its major role in crop uptake and leaching. Furthermore, the measured initial soil total $\mathrm{P}$ concentration was considered in the model as the sum of soluble orthophosphates and labile adsorbed $\mathrm{P}$, with the remaining $\mathrm{P}$ assumed to be nonreactive during the P sorption simulation. The phosphorus concentration in the soil solution was considered as the dissolved reactive P fraction (DRP) [47]. Similar approaches have been previously used in numerous modeling studies $[25,28,49]$. Phosphorus sorption in soil was simulated for 7 days (168 h).

\subsection{Inverse P Dynamics Modeling}

The Levenberg-Marquardt optimization algorithm [50], in combination with the HYDRUS-1D numerical code [46], was used to inversely estimate the sorption coefficient for various treatments. Different approaches that are routinely used in inverse modeling are provided in Hopmans and Šimůnek [51] and Vrugt et al. [32]. The optimized solute reaction parameters were determined by minimizing the differences between the observed and simulated state variables (i.e., $\mathrm{PO}_{4}-\mathrm{P}$ fluxes). The sum of squares of these the differences is expressed using an objective function, $\emptyset$, which may be defined as [29]:

$$
\varnothing(\beta, y)=\sum_{j=1}^{j=m_{y}} v_{j} \sum_{i=1}^{i=n_{j}} w_{i, j}\left[y_{j}^{*}\left(z, t_{i}\right)-y_{j}\left(z, t_{i}, \beta\right)\right]^{2},
$$

where the right-hand side represents the residuals between the space-time variables, which are measured $\left(y_{j}^{*}\right)$ and model-predicted $\left(y_{j}\right)$ using the solute reaction parameters of the optimized parameter vector, $\beta$. The first summation sums the residuals for all measurement types $m_{y}$ (i.e., leachate solute fluxes). The variable $n_{j}$ in the second summation denotes the number of measurements for a particular measurement type $j$. Assuming that the measurement errors in a specific measurement type are independent and uncorrelated, the weighting factor $v_{j}$ can be selected so that different data types are weighted equally using the reciprocal of the variance of the measurement type $j$ [52]. The sorption coefficient $K_{d}$ for $\mathrm{P}$ was estimated inversely using the $\mathrm{PO}_{4}-\mathrm{P}$ concentrations measured in the leachate (which were transformed into the cumulative $\mathrm{PO}_{4}-\mathrm{P}$ flux).

The quality of the fit was evaluated by comparing the simulated and measured leachate volumes and leachate concentrations using the coefficient of determination $\left(R^{2}\right)$ :

$$
R^{2}=\left\lceil\frac{\sum_{i=1}^{N}\left(O_{i}-\bar{O}\right)\left(P_{i}-\bar{P}\right)}{\left[\sum_{i=1}^{N}\left(O_{i}-\bar{O}\right)^{2}\right]^{0.5}\left[\sum_{i=1}^{N}\left(P_{i}-\bar{P}\right)^{2}\right]^{0.5}}\right\rceil,
$$

where $O_{i}$ are the observation data points, $P_{i}$ are the model predictions, $\bar{O}$ is an average observation, $\bar{P}$ is an average prediction, and $N$ is the sample size.

\section{Results and Discussion}

\subsection{Impact of Amendments on Soil Water Retention and Hydraulic Properties}

The effects of the compost and biochar addition on the shape of the soil water retention and hydraulic conductivity curves of two soil types-i.e., Terra Rosa and Rendzina-are illustrated in 
Figures 1 and 2. For the majority of treatments, the soil water retention increased compared to the control, resulting in an increase in the saturated water content, field capacity, and available water content. Similar results were obtained by Villagra-Mendoza and Horn [16] and Mohawesh and Durner [17] for soils amended with biochar, and Karbout et al. [53] for soils amended with compost. An increase in soil water retention is related to an increase in the number of macro and medium pores due to the addition of compost or biochar, which affects the total porosity and the pore size distribution. In two treatments of the Terra Rosa soil type (TCSS_P, TCSS_P+), the addition of compost or biochar resulted in a lower/identical saturated water content. For these particular treatments, $\theta_{s}$ decreased from 0.450 to 0.437 (TCSS_P), or it stayed unchanged at $0.450 \mathrm{~cm}^{3} \mathrm{~cm}^{-3}$ (TCSS_P+, Table 4), which may be associated with the heterogeneity of the soil-amendment mixture and uncertainties during the retention curve estimation. The control soils, Terra Rosa (T_0, T_P) and Rendzina (R_0, R_P), had saturated water contents of 0.45 and $0.36 \mathrm{~cm}^{3} \mathrm{~cm}^{-3}$, respectively (Tables 4 and 5), thus the increase due to the amendments was not particularly high $\left(0.01-0.07 \mathrm{~cm}^{3} \mathrm{~cm}^{-3}\right.$; Figure 1). Razzaghi et al. [4] conducted a statistical meta-analysis of the literature published between 2010 and 2019 and quantified biochar's impacts on soil water retention variables (Field capacity-FC; wilting point-WP; available water content-AW). FC and WP significantly increased for the coarse-textured soils (by $51 \%$ and $47 \%$, respectively), and moderately for the medium-textured soils (by $13 \%$ and $9 \%$, respectively). For the fine-textured soils, the FC remained unchanged $(<1 \%)$, but the WP marginally decreased by $5 \%$. Biochar significantly increased the AW in the coarse-textured soils (by $45 \%$ ) compared to the mediumand fine-textured soils (by $21 \%$ and $14 \%$, respectively), suggesting that biochar may provide a greater benefit for coarse-textured soils. A similar effect was seen in the presented experiments where both soil types, Terra Rosa and Rendzina, had a silty clay loam texture with $<7 \%$ sand.

On the other hand, the effect of the addition of compost or biochar on the unsaturated hydraulic conductivity $(K)$ was not so distinctive (Figure 2). In both soils, Terra Rosa and Rendzina, with the added amendments, the shape of the hydraulic conductivity curve and the measured data range showed slight changes following the retention data, with some larger changes seen in TBSS_P, TBSSP+, TCSS_P, and RBSS_P compared to the control columns. Schneider et al. [54] compared the effects of two types of composts (urban waste and co-compost of green wastes and sewage sludge) at a field scale on near-saturated infiltration using a tension disc infiltrometer. The effect on the near-saturated hydraulic conductivity was not identifiable when analyzing only the average plot-scale values. Still, it could be shown when accounting for additional heterogeneity: application date, structure, and tillage. In our experiment, the time needed for structure development, settling, and a column scale limited the apparent effects of the amendment treatments. Therefore, it should be further tested in a long-term study conducted on a field scale. Similar to minor changes in water retention properties, the hydraulic conductivity was also altered only slightly.

The fitting of the VC model to the soil water retention curves and the resulting set of soil hydraulic parameters are presented in Table 4 for Terra Rosa and in Table 5 for Rendzina. The accuracy of the soil hydraulic property estimation is generally limited by the error of the measurement method. The saturated hydraulic conductivity $\left(K_{s}\right)$ is reported to be one of the most variable soil properties, having predictions with large uncertainty. Thus, various approaches like developing new piecewise-continuous hydraulic functions based on in situ and laboratory measurements [55], estimating $K_{s}$ from pedotransfer functions (PTFs) [56]), or using inverse modeling [57] have been proposed. Here, the $K(h)$ function near saturation was obtained by the linear interpolation between the measured values $K_{k}$ (from the evaporation experiment) and $K_{s}$ (from the leaching experiment).

The addition of soil amendments did not show an apparent effect on $K_{s}$. However, to properly evaluate this, a more focused experiment is needed. The total range of $K_{s}$ was from 4.71 to $7.23 \mathrm{~cm} \mathrm{~d}^{-1}$ in all the treatments, including the controls. However, in both soil types, the evaluated $K-h$ curves and $K_{s}$ shifted in both directions, showing an increase or decrease compared to the control. Similar observations were made by Villagra-Mendoza and Horn [16], who reported a decrease in the saturated hydraulic conductivity when amendments were added. This is somewhat contrary to the findings of 
the positive impact of compost and biochar amendments on soil hydraulic properties [11]. In our study, the compost and biochar were sieved through a $2 \mathrm{~mm}$ sieve before mixing with the soil, with a relatively short period available for soil-amendment mixture settling in the columns, probably insufficient for the development of a defined structure and aggregate formation in the soil [54].
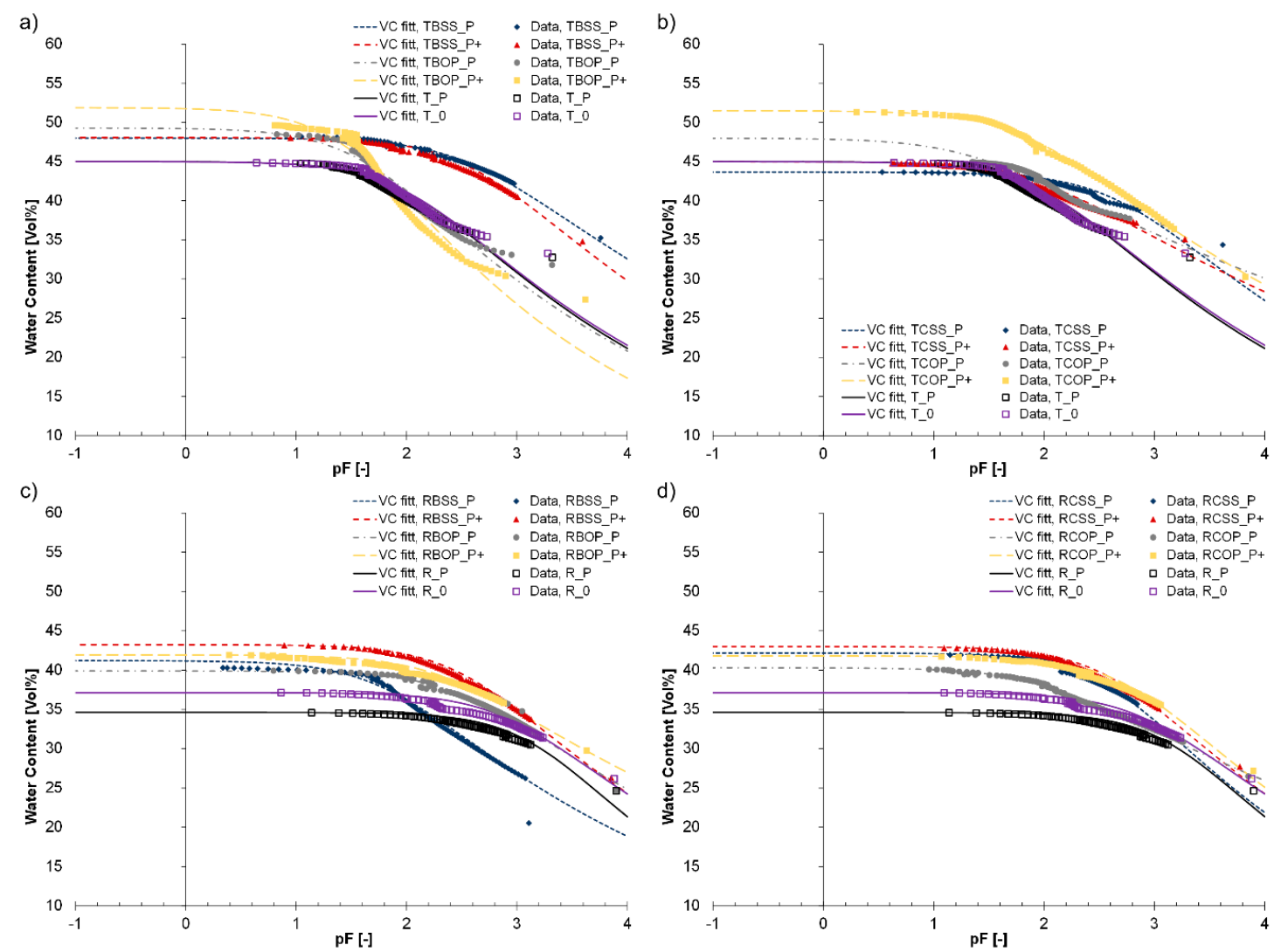

Figure 1. Measured soil water retention points and reproduced soil water retention curves for the Terra Rosa (T) and Rendzina (R) soils amended with biochar (B) or compost (C) produced from sewage sludge (SS) or olive pomace (OP) at two application rates, calculated on a P content basis (according to legislation, P; and 10 times higher rate, $\mathrm{P}+$ ): (a) Terra Rosa with biochar waste, (b) Terra Rosa with composted waste, (c) Rendzina with biochar waste, and (d) Rendzina with composted waste.

Table 4. The soil hydraulic parameters for the VC model determined using the evaporation experiment on the Terra Rosa (T) soil amended with biochar (B) or compost (C) produced from sewage sludge (SS) or olive pomace (OP) at two application rates, calculated on a $\mathrm{P}$ content basis (according to legislation, $\mathrm{P}$; and 10 times higher rate, $\mathrm{P}+$ ).

\begin{tabular}{|c|c|c|c|c|c|c|c|}
\hline $\begin{array}{c}\text { Treatment } \\
\text { Abbreviation }\end{array}$ & $\begin{array}{c}\theta_{s} \\
\left(\mathrm{~cm}^{3} \mathrm{~cm}^{-3}\right)\end{array}$ & $\begin{array}{c}\alpha \\
\left(\mathrm{cm}^{-1}\right)\end{array}$ & $\begin{array}{c}n \\
(-)\end{array}$ & $\begin{array}{c}K_{s} \\
\left(\mathrm{~cm} \mathrm{~d}^{-1}\right)\end{array}$ & $\begin{array}{c}l \\
(-)\end{array}$ & $\begin{array}{c}\theta_{k} \\
\left(\mathrm{~cm}^{3} \mathrm{~cm}^{-3}\right)\end{array}$ & $\begin{array}{c}K_{k} \\
\left(\mathrm{~cm} \mathrm{~d} \mathrm{~d}^{-1}\right)\end{array}$ \\
\hline TBSS_P & 0.480 & 0.00247 & 1.12 & 7.07 & -4.80 & 0.480 & 0.019 \\
\hline TBSS_P+ & 0.481 & 0.00238 & 1.15 & 6.68 & -4.51 & 0.480 & 0.022 \\
\hline TBOP_P & 0.493 & 0.0234 & 1.16 & 5.72 & -5.08 & 0.457 & 0.282 \\
\hline TBOP_P+ & 0.519 & 0.032 & 1.19 & 7.07 & -3.57 & 0.437 & 0.759 \\
\hline TCSS_P & 0.437 & 0.00195 & 1.16 & 6.59 & -3.57 & 0.437 & 0.026 \\
\hline TCSS_P+ & 0.450 & 0.011 & 1.10 & 6.68 & 4.89 & 0.448 & 0.047 \\
\hline TCOP_P & 0.480 & 0.0461 & 1.08 & 6.94 & 10.00 & 0.441 & 0.525 \\
\hline TCOP_P+ & 0.515 & 0.0135 & 1.11 & 6.11 & -6.00 & 0.513 & 0.158 \\
\hline T_P & 0.450 & 0.00895 & 1.17 & 6.37 & 4.59 & 0.434 & 0.575 \\
\hline T_0 & 0.450 & 0.00914 & 1.16 & 6.81 & 3.99 & 0.446 & 0.093 \\
\hline
\end{tabular}




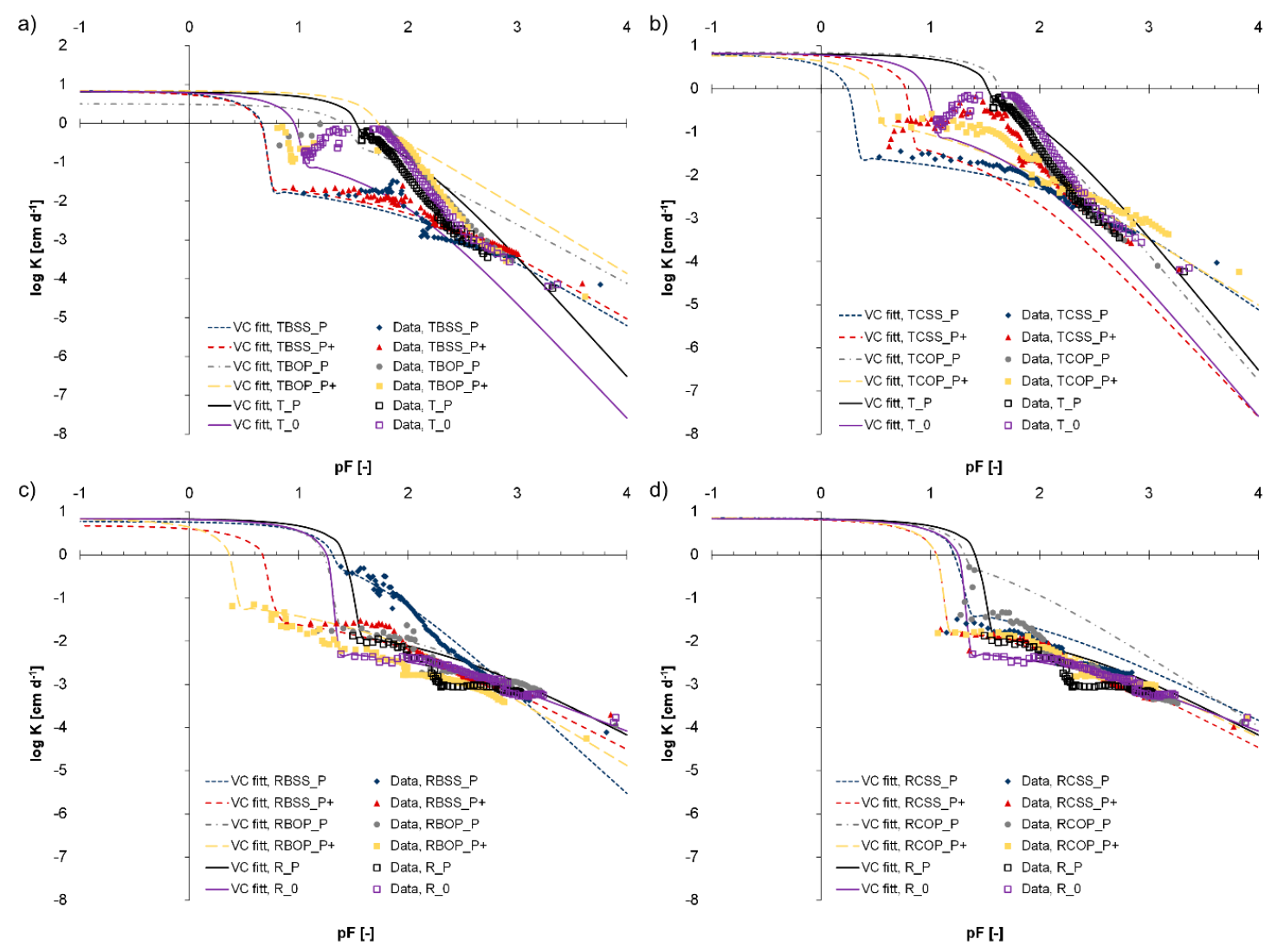

Figure 2. Measured points and reproduced hydraulic conductivity curves for the Terra Rosa (T) and Rendzina (R) soils amended with biochar (B) or compost (C) produced from sewage sludge (SS) or olive pomace (OP) at two application rates, calculated on a $\mathrm{P}$ content basis (according to legislation, $\mathrm{P}$; and 10 times higher rate, $\mathrm{P}+$ ): (a) Terra Rosa with biochar waste, (b) Terra Rosa with composted waste, (c) Rendzina with biochar waste, and (d) Rendzina with composted waste.

Table 5. Soil hydraulic parameters for the VC model determined using the evaporation experiment on the Rendzina (R) soil amended with biochar (B) or compost (C) produced from sewage sludge (SS) or olive pomace $(\mathrm{OP})$ at two application rates, calculated on a $\mathrm{P}$ content basis (according to legislation, $\mathrm{P}$; and 10 times higher rate, $\mathrm{P}+$ ).

\begin{tabular}{|c|c|c|c|c|c|c|c|}
\hline $\begin{array}{c}\text { Treatment } \\
\text { Abbreviation }\end{array}$ & $\begin{array}{c}\theta_{s} \\
\left(\mathrm{~cm}^{3} \mathrm{~cm}^{-3}\right)\end{array}$ & $\begin{array}{c}\alpha \\
\left(\mathrm{cm}^{-1}\right)\end{array}$ & $\begin{array}{c}n \\
(-)\end{array}$ & $\begin{array}{c}K_{s} \\
\left(\mathrm{~cm} \mathrm{~d}^{-1}\right)\end{array}$ & $\begin{array}{c}l \\
(-)\end{array}$ & $\begin{array}{c}\theta_{k} \\
\left(\mathrm{~cm}^{3} \mathrm{~cm}^{-3}\right)\end{array}$ & $\begin{array}{c}K_{k} \\
\left(\mathrm{~cm} \mathrm{~d}^{-1}\right)\end{array}$ \\
\hline RBSS_P & 0.412 & 0.015 & 1.16 & 5.97 & -0.15 & 0.398 & 0.537 \\
\hline RBSS_P+ & 0.432 & 0.00272 & 1.17 & 4.71 & -6.00 & 0.432 & 0.029 \\
\hline RBOP_P & 0.400 & 0.0018 & 1.18 & 7.07 & -6.00 & 0.399 & 0.024 \\
\hline RBOP_P+ & 0.420 & 0.0043 & 1.12 & 6.94 & -6.00 & 0.419 & 0.065 \\
\hline RCSS_P & 0.422 & 0.0023 & 1.21 & 7.16 & -5.95 & 0.420 & 0.047 \\
\hline RCSS_P+ & 0.430 & 0.00219 & 1.18 & 6.94 & -5.80 & 0.429 & 0.019 \\
\hline RCOP_P & 0.403 & 0.0093 & 1.10 & 7.07 & -6.00 & 0.397 & 0.525 \\
\hline RCOP_P & 0.418 & 0.00146 & 1.19 & 7.24 & -6.00 & 0.418 & 0.019 \\
\hline R_P & 0.372 & 0.00107 & 1.18 & 6.94 & -6.00 & 0.371 & 0.014 \\
\hline R_0 & 0.346 & 0.00062 & 1.25 & 6.94 & -6.00 & 0.346 & 0.005 \\
\hline
\end{tabular}

The measured cumulative leachates from columns filled with the Terra Rosa (T) and Rendzina (R) soils amended with biochar (B) or compost (C) produced from sewage sludge (SS) or olive pomace (OP) at two application rates, calculated on a P content basis (according to legislation, P; and a 10 times higher rate, $\mathrm{P}+$ ), are presented in Figures 3 and 4 , respectively. The $R^{2}$ values for the simulation efficiency show that the HYDRUS-1D model successfully estimated the water flow with a high efficiency 
(0.99, Table 6), which was expected because the water flow in non-structured homogeneous soils under controlled conditions is usually very well predicted using HYDRUS-1D [27,28,58].

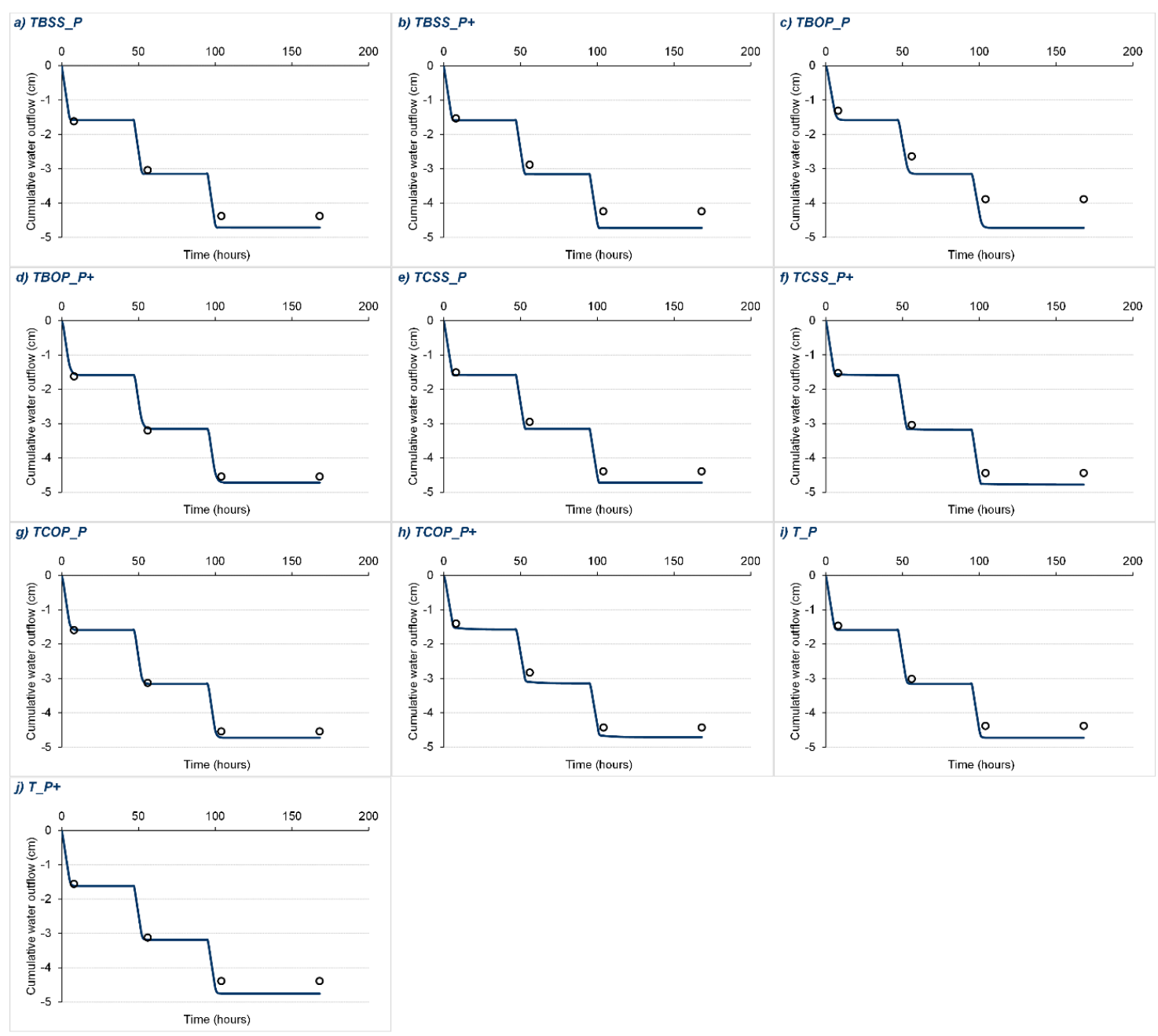

Figure 3. (a-j) Measured (dots) vs. simulated (HYDRUS-1D; line) cumulative leachates from columns filled with the Terra Rosa (T) soil amended with biochar (B) or compost (C) produced from sewage sludge (SS) or olive pomace (OP) at two application rates, calculated on a P content basis (according to legislation, $\mathrm{P}$; and a 10 times higher rate, $\mathrm{P}+$ ).

Table 6. An averaged leachate amount $(\mathrm{cm})$ measured in a column experiment and simulated with HYDRUS-1D using optimized VC parameters for the Terra Rosa (T) and Rendzina (R) soils amended with biochar (B) or compost (C) produced from sewage sludge (SS) or olive pomace (OP) at two application rates, calculated on a P content basis (according to legislation, $\mathrm{P}$; and a 10 times higher rate, $\mathrm{P}+)(n=4)$.

\begin{tabular}{|c|c|c|c|c|c|c|c|c|c|c|c|}
\hline & & TBSS_P & TBSS_P+ & TBOP_P & TBOP_P+ & TCSS_P & TCSS_P+ & TCOP_P & TCOP_P+ & T_P & T_0 \\
\hline \multirow{4}{*}{ 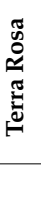 } & $\begin{array}{l}\text { Measured } \\
\text { vol. }(\mathrm{cm})\end{array}$ & 4.38 & 4.24 & 3.89 & 4.54 & 4.39 & 4.44 & 4.54 & 4.43 & 4.38 & 4.39 \\
\hline & $\begin{array}{c}\text { Simulated } \\
\text { vol. }(\mathrm{cm})\end{array}$ & 4.71 & 4.72 & 4.72 & 4.72 & 4.72 & 4.72 & 4.71 & 4.71 & 4.72 & 4.72 \\
\hline & $R^{2}$ & 0.99 & 0.99 & 0.99 & 0.99 & 0.99 & 0.99 & 0.99 & 0.99 & 0.99 & 0.99 \\
\hline & & RBSS_P & RBSS_P+ & RBOP_P & RBOP_P+ & RCSS_P & RCSS_P+ & RCOP_P & RCOP_P+ & R_P & R_0 \\
\hline \multirow{3}{*}{ 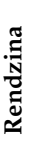 } & $\begin{array}{l}\text { Measured } \\
\text { vol. }(\mathrm{cm})\end{array}$ & 4.46 & 4.13 & 4.55 & 4.09 & 4.33 & 4.56 & 4.71 & 4.54 & 4.65 & 4.44 \\
\hline & $\begin{array}{l}\text { Simulated } \\
\text { vol. }(\mathrm{cm})\end{array}$ & 4.72 & 4.72 & 4.73 & 4.72 & 4.72 & 4.73 & 4.73 & 4.73 & 4.72 & 4.72 \\
\hline & $R^{2}$ & 0.99 & 0.99 & 0.99 & 0.99 & 0.99 & 0.99 & 0.99 & 0.99 & 0.99 & 0.99 \\
\hline
\end{tabular}




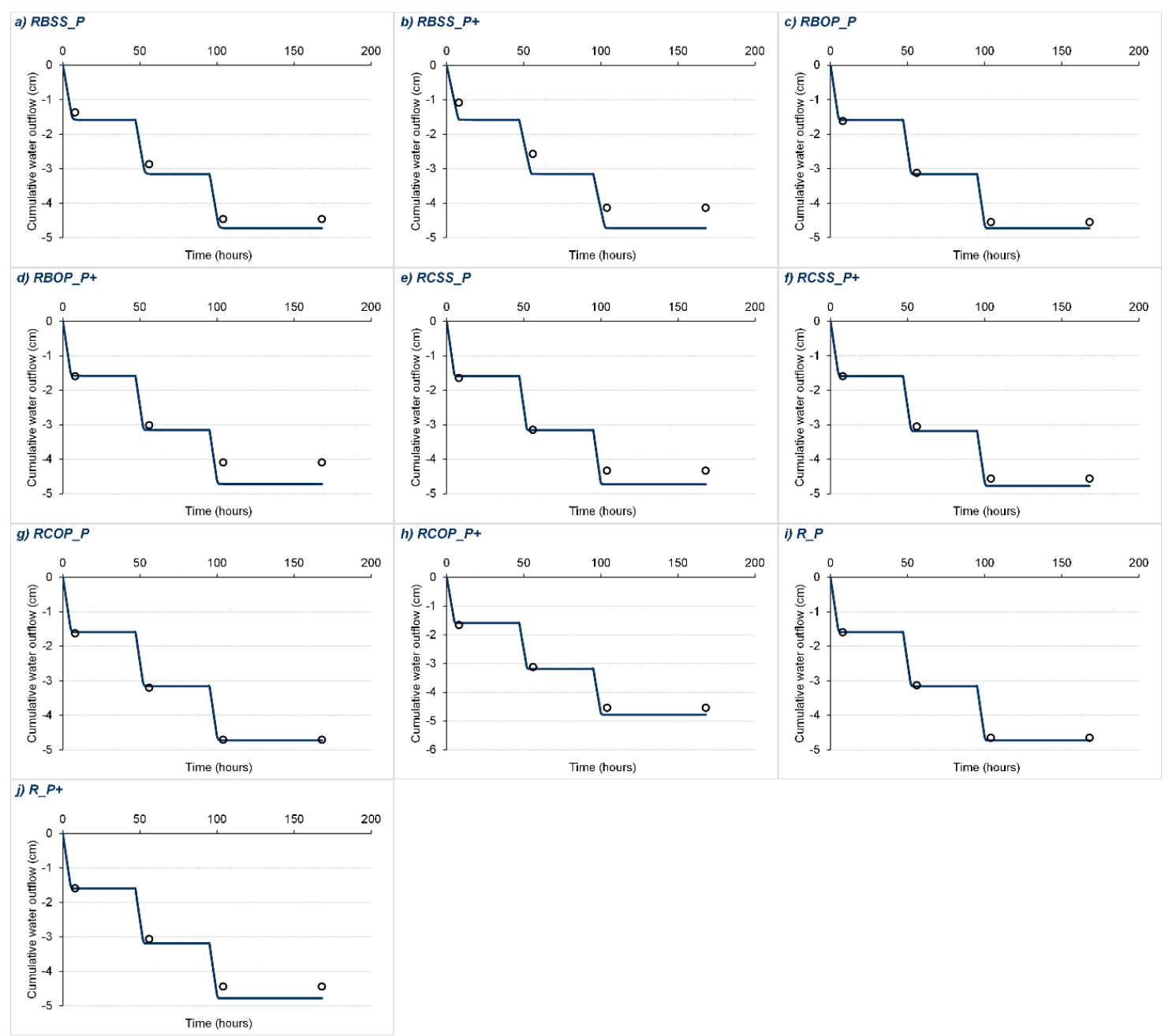

Figure 4. (a-j) Measured (dots) vs. simulated (HYDRUS-1D; line) cumulative leachates from columns filled with the Rendzina (R) soil amended with biochar (B) or compost (C) produced from sewage sludge (SS) or olive pomace (OP) at two application rates, calculated on a P content basis (according to legislation, $\mathrm{P}$; and a 10 times higher rate, $\mathrm{P}+$ ).

\subsection{Soil Amendments and $\mathrm{PO}_{4}-\mathrm{P}$ Leaching Potential}

After the water flow was successfully simulated, the $\mathrm{P}$ transport for each treatment and control was modeled using the measured $\mathrm{PO}_{4}-\mathrm{P}$ cumulative fluxes (Figures 5 and 6 ) in inverse numerical simulations to estimate the distribution coefficient, $K_{d}$ (Table 7).

The sorption coefficient is one of the most relevant parameters during the estimation of element mobility in soils [59]. The simulated and experimental data showed that the P transport was limited in both the Terra Rosa and Rendzina soils amended with either compost or biochar produced from sewage sludge or olive pomace and applied at two application rates (i.e., $\mathrm{P}$ and $\mathrm{P}+$ ) due to its high sorption in soil. The sorption was in the range from 21.24 to $53.68 \mathrm{~cm}^{3} \mathrm{~g}^{-1}$ and showed a relatively uniform sorption capacity for all the treatments and controls in the experiment (Table 7). This finding is in agreement with a literature review that showed that the $K_{d}$ in most soils with similar physicochemical characteristics ranged from 19 to $185 \mathrm{~cm}^{3} \mathrm{~g}^{-1}$ [60,61]. Furthermore, the sorption coefficient values were found to vary among all the treatments. Their sensitivity in estimation in the field, laboratory, and numerical studies is well known [33]. The dissolved P was found to interact strongly with particulates, such as aluminosilicates (clays), metal oxides, and hydroxides, particularly of iron (Fe) and aluminum (Al) [62], thus showing the high sorption potential. An increase in particular treatments was assumed to be in response to adding the organic material (olive pomace or sewage sludge), 
which was confirmed to be the right approach in many studies [63-66]. In both soil types, a minimal leaching potential was found, ranging from 0.03 to $0.05 \mathrm{mg} \mathrm{cm}^{-2}$ for the Terra Rosa treatments and from 0.02 to $0.04 \mathrm{mg} \mathrm{cm}^{-2}$ for the Rendzina treatments (cumulative $\mathrm{PO}_{4}-\mathrm{P}$ flux). The high sorption coefficient found in the Rendzina control (R_P: $52.83 \mathrm{~cm}^{3} \mathrm{~g}^{-1}$ ) can be associated with the higher values of organic C (6.1\%). Also, as reported recently by [67], carbon-rich materials such as biochars can increase the $\mathrm{P}$ adsorption affinity. Overall, the results showed a very poor $\mathrm{P}$ mobility even at high $\mathrm{P}$ concentrations in the soil (e.g., a $\mathrm{P}+$ amendment application rate). The modeling results and $K_{d}$ estimations corresponded well with the experimentally obtained P concentrations in the leachate, which were in the range from 0.01 to $0.04 \mathrm{mg} \mathrm{L}^{-1}$. Therefore, the results showed that the majority of the $\mathrm{P}$ applied with the soil amendments was strongly adsorbed in the topsoil layer, even if applied in elevated amounts. The same conclusion was obtained by, e.g., Elmi et al. [27], Naseri et al. [28], or Kadyampakeni et al. [25], who showed that $98 \%$ of the added P remained in approximately the top $20 \mathrm{~cm}$ of the soil columns, indicating the low P mobility through the soil profile. As found by previous researchers, biochar application improves soil quality and fertility for crop productivity, providing ecosystem services such as the immobilization and transformation of contaminants [68] -in our case, P. Similar results are found for compost, which can result in an increased cation exchange capacity and nutrient content-e.g., $\mathrm{N}, \mathrm{P}, \mathrm{K}$, and $\mathrm{Mg}$ [69].

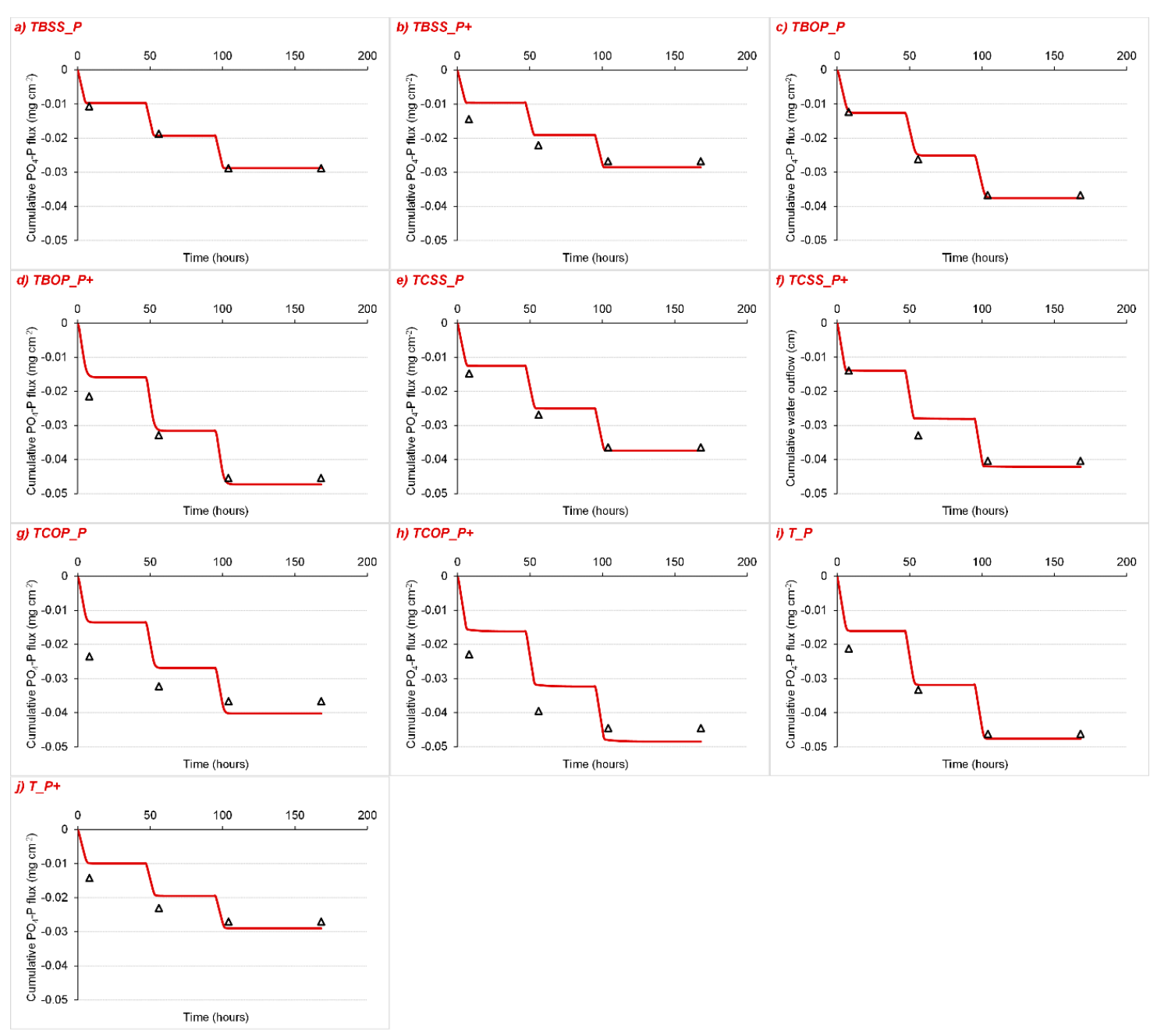

Figure 5. (a-j) Measured (dots) vs. simulated (HYDRUS-1D; line) cumulative $\mathrm{PO}_{4}-\mathrm{P}$ leachate fluxes from columns filled with the Terra Rosa (T) soil amended with biochar (B) or compost (C) produced from sewage sludge (SS) or olive pomace (OP) at two application rates, calculated on a $\mathrm{P}$ content basis (according to legislation, $\mathrm{P}$; and a 10 times higher rate, $\mathrm{P}+$ ). 


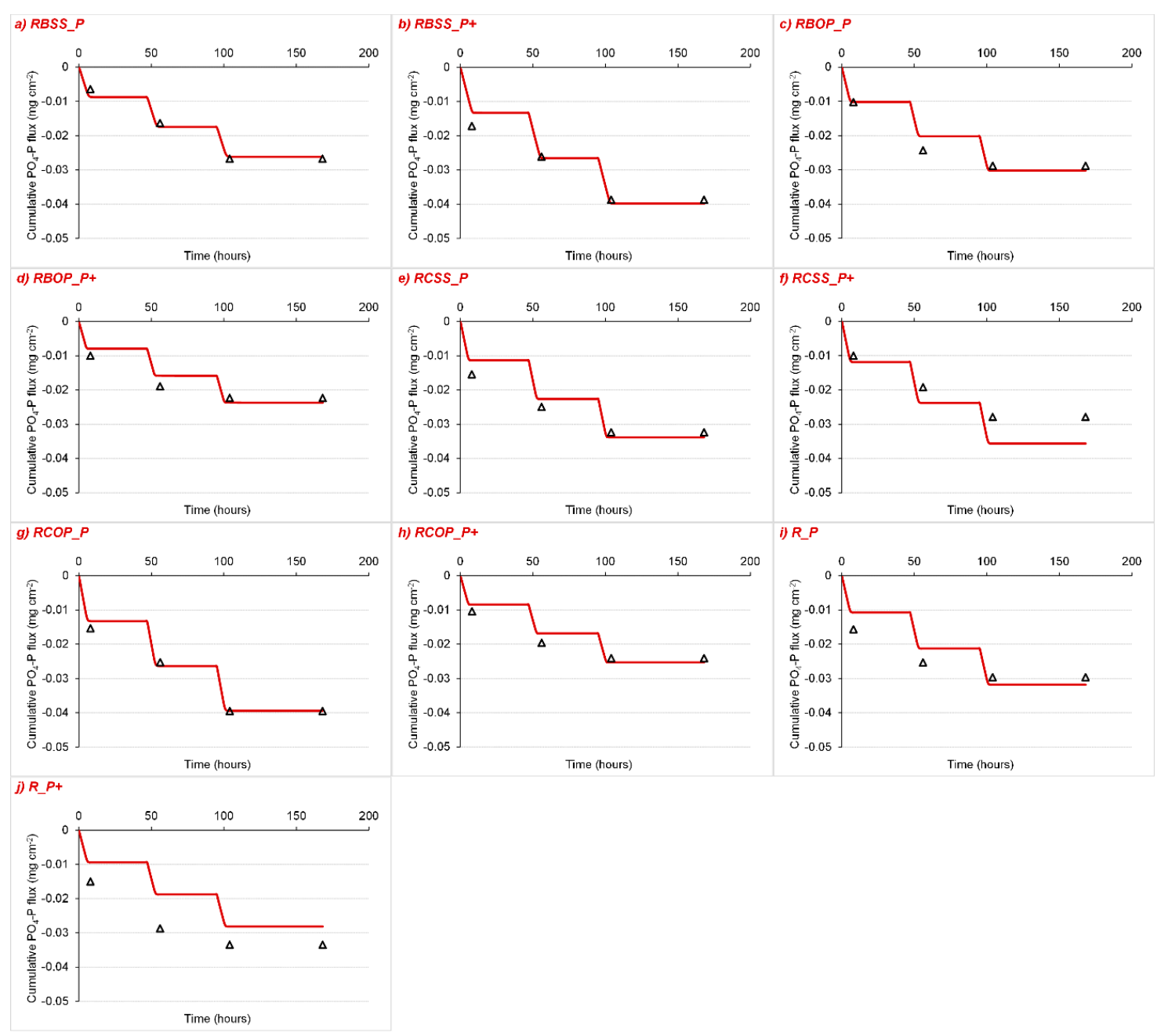

Figure 6. (a-j) Measured (dots) vs. simulated (HYDRUS-1D; line) cumulative $\mathrm{PO}_{4}-\mathrm{P}$ leachate fluxes from columns filled with the Rendzina (R) soil amended with biochar (B) or compost (C) produced from sewage sludge (SS) or olive pomace (OP) at two application rates, calculated on a $\mathrm{P}$ content basis (according to legislation, $\mathrm{P}$; and a 10 times higher rate, $\mathrm{P}+$ ).

Table 7. Inversely estimated P sorption coefficients, $K_{d}\left(\mathrm{~cm}^{3} \mathrm{~g}^{-1}\right)$, in the Terra Rosa $(\mathrm{T})$ and Rendzina (R) soils amended with biochar (B) or compost (C) produced from sewage sludge (SS) or olive pomace (OP) at two application rates, calculated on a P content basis (according to legislation, P; and a 10 times higher rate, $\mathrm{P}+$ ), using HYDRUS-1D.

\begin{tabular}{|c|c|c|c|c|c|c|c|c|c|c|c|}
\hline & & TBSS_P & TBSS_P+ & TBOP_P & TBOP_P+ & TCSS_P & TCSS_P+ & TCOP_P & TCOP_P+ & T_P & T_0 \\
\hline \multirow{3}{*}{ 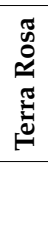 } & $K_{d}$ & 35.13 & 53.68 & 27.27 & 22.51 & 28.34 & 26.48 & 26.23 & 23.07 & 29.98 & 37.57 \\
\hline & $R^{2}$ & 0.99 & 0.98 & 0.98 & 0.99 & 0.98 & 0.95 & 0.96 & 0.92 & 0.99 & 0.96 \\
\hline & & RBSS_P & RBSS_P+ & RBOP_P & RBOP_P+ & RCSS_P & RCSS_P+ & RCOP_P & RCOP_P+ & R_P & R_0 \\
\hline \multirow{2}{*}{ 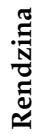 } & $K_{d}$ & 34.67 & 30.01 & 27.11 & 34.41 & 25.22 & 28.38 & 21.24 & 44.89 & 52.83 & 30.64 \\
\hline & $R^{2}$ & 0.99 & 0.99 & 0.93 & 0.94 & 0.99 & 0.93 & 0.99 & 0.97 & 0.96 & 0.93 \\
\hline
\end{tabular}




\section{Conclusions}

The addition of compost or biochar produced from sewage sludge or olive pomace at two P application rates (low: $12 \mathrm{mg} \mathrm{L}^{-1}$; high: $120 \mathrm{mg} \mathrm{L}^{-1}$ ), calculated on a P content basis, slightly changed the Terra Rosa and Rendzina soil hydraulic properties and influenced the P immobilization in the soil. Compared to the control, the soil water retention increased with the majority of amendment treatments, resulting in minor increases in the saturated water content and field capacity (for both Terra Rosa and Rendzina soil). The time needed for the structure development and soil particle settling, as well as the column scale at which this study was conducted, limited the apparent effects of the amendments on the soil hydraulic conductivity. The soil hydraulic properties showed a reliable fit when a modified van Genuchten model was used, which was also confirmed for water flow modeling using HYDRUS-1D in a leaching experiment $\left(R^{2} 0.99\right)$. The results showed a high P sorption capacity in all the amendment treatments, with a $K_{d}$ ranging from 21.24 to $53.68 \mathrm{~cm}^{3} \mathrm{~g}^{-1}$, and a high reliability when an inverse modeling procedure was used to estimate the $K_{d}\left(R^{2} 0.93-0.99\right)$. Adding sewage sludge or olive pomace composts or biochars at two application rates calculated on a P content basis (according to legislation and a 10 times higher rate) improved the Terra Rosa and Rendzina soil water retention and did not increase the P mobility in soil. The experiment showed a minimal $P$ mobility even when $P$ was applied in higher amounts through amendment additions, thus not posing any environmental concerns. Contrary, it is indicative that organic amendments (compost or biochar) improve soil properties it terms of nutrient retention as one of the ecosystem services. Additional long-term field-scale experiments are needed to clarify further the full agricultural potential of these amendments and their effects on soil hydrology, as well as to confirm that the P added with the amendments does not pose an environmental concern.

Supplementary Materials: The following are available online at http://www.mdpi.com/2073-4395/10/8/1163/s1, Table S1. Basic chemical properties, macro-, microelements and trace metals in treatments with the Terra Rosa (T) or Rendzina (R) soils amended with biochar (B) or compost (C) produced from sewage sludge (SS) or olive pomace $(\mathrm{OP})$ at two application rates calculated on a $\mathrm{P}$ content basis (according to legislation, $\mathrm{P}$; and a ten times higher rate, $\mathrm{P}+)(n=4)$.

Author Contributions: Conceptualization, V.F., M.Č., M.R., I.P. (Igor Pasković) and I.P. (Igor Palčić); methodology, V.F., M.Č., M.R. and I.P. (Igor Pasković); software, V.F. and J.Š.; formal analysis, V.F., L.F., G.O., I.B., I.M., V.K., I.P. (Igor Pasković), I.P. (Igor Palčić), S.G.B., Z.U. and D.B.; data curation, M.Č., I.P. (Igor Pasković), I.P. (Igor Palčić), S.G.B., Z.U. and D.B.; writing—original draft preparation, V.F., J.Š., L.F., I.B., I.M. and A.F.; writing—review and editing, V.F., J.Š., L.F., G.O., I.B., V.K. and D.R.; visualization, V.F. and V.K.; project administration, I.P. (Igor Pasković) and I.P. (Igor Palčić); funding acquisition, D.B. All authors have read and agreed to the published version of the manuscript

Funding: This research was funded by the Croatian Science Foundation (HRZZ) Program for encouraging research and development activities in the field of climate change, and The Environmental Protection and Energy Efficiency Fund (contract No. PKP-2016-06-9041). David Robinson was supported by the Natural Environment Research Council award number NE/R016429/1 as part of the UK-SCaPE program delivering National Capability. The APC was covered by the Open Access Publication Fund, University of Zagreb Faculty of Agriculture.

Acknowledgments: The authors would like to thank the staff of the municipal companies for their cooperation and assistance during the experiment set-up.

Conflicts of Interest: The authors declare no conflict of interest.

\section{References}

1. Diacono, M.; Montemurro, F. Long-term effects of organic amendments on soil fertility. A review. Agron. Sustain. Dev. 2010, 30, 401-422. [CrossRef]

2. Marks, E.A.N.; Mattana, S.; Alcañiz, J.M.; Pérez-Herrero, E.; Domene, X. Gasifier biochar effects on nutrient availability, organic matter mineralization, and soil fauna activity in a multi-year Mediterranean. Agric. Ecosyst. Environ. 2016, 215, 30-39. [CrossRef] 
3. Ye, S.; Zeng, G.; Wu, H.; Liang, J.; Zhang, C.; Dai, J.; Xiong, W.; Song, B.; Wu, S.; Yu, J. The effects of activated biochar addition on remediation efficiency of co-composting with contaminated wetland soil. Resour. Conserv. Recycl. 2019, 140, 278-285. [CrossRef]

4. Razzaghi, F.; Obour, P.B.; Arthur, E. Does biochar improve soil water retention? A systematic review and meta-analysis. Geoderma 2020, 361, 114055. [CrossRef]

5. Wang, B.; Gao, B.; Fang, J. Recent advances in engineered biochar productions and applications. Crit. Rev. Environ. Sci. Technol. 2017, 47, 2158-2207. [CrossRef]

6. Wu, H.P.; Lai, C.; Zeng, G.M.; Liang, J.; Chen, J.; Xu, J.J.; Dai, J.; Li, X.D.; Liu, J.F.; Chen, M.; et al. The interactions of composting and biochar and their implications for soil amendment and pollution remediation: A review. Crit. Rev. Biotechnol. 2017, 37, 754-764. [CrossRef] [PubMed]

7. Mukherjee, A.; Lal, R. Biochar impacts on soil physical properties and greenhouse gas emissions. Agronomy 2013, 3, 313-339. [CrossRef]

8. Mukherjee, A.; Zimmerman, A.R. Organic carbon and nutrient release from a range of laboratory-produced biochars and biochar-soil mixtures. Geoderma 2013, 193, 122-130. [CrossRef]

9. Munoz, C.; Gongora, S.; Zagal, E. Use of biochar as a soil amendment: A brief review. Chil. J. Agric. Anim. Sci. 2016, 32, 37-47.

10. Yu, H.; Zou, W.; Chen, J.; Chen, H.; Yu, Z.; Huang, J.; Tang, H.; Wei, X.; Gao, B. Biochar amendment improves crop production in problem soils: A review. J. Environ. Manag. 2019, 232, 8-21. [CrossRef]

11. Kranz, C.N.; McLaughlin, R.A.; Johnson, A.; Miller, G.; Heitman, J.L. The effects of compost incorporation on soil physical properties in urban soils-A concise review. J. Environ. Manag. 2020, 261, 110209. [CrossRef] [PubMed]

12. Lal, R. Restoring soil quality to mitigate soil degradation. Sustainability 2015, 7, 5875-5895. [CrossRef]

13. Rizzardini, C.B.; Goi, D. Sustainability of domestic sewage sludge disposal. Sustainability 2014, 6, $2424-2434$. [CrossRef]

14. Toková, L.; Igaz, D.; Horák, J.; Aydin, E. Effect of Biochar Application and Re-Application on Soil Bulk Density, Porosity, Saturated Hydraulic Conductivity, Water Content and Soil Water Availability in a Silty Loam Haplic Luvisol. Agronomy 2020, 10, 1005. [CrossRef]

15. Sun, Y.; Gao, B.; Yao, Y.; Fang, J.; Zhang, M.; Zhou, Y.; Chen, H.; Yang, L. Effects of feedstock type, production method, and pyrolysis temperature on biochar and hydrochar properties. Chem. Eng. J. 2014, 240, 574-578. [CrossRef]

16. Villagra-Mendoza, K.; Horn, R. Effect of biochar addition on hydraulic functions of two textural soils. Geoderma 2018, 326, 88-95. [CrossRef]

17. Mohawesh, O.; Durner, W. Effects of Bentonite, Hydrogel and Biochar Amendments on Soil Hydraulic Properties from Saturation to Oven Dryness. Pedosphere 2019, 29, 598-607. [CrossRef]

18. Zhuo, A.; He, L.; Zhao, H. Effect of organic acids on inorganic phosphorus transformation in soils and its readily available phosphate. Acta Ecol. Sin. 2009, 29, 4061-4069.

19. Cordell, D.; White, S. Peak phosphorus: Clarifying the key issues of a vigorous debate about long-term phosphorus security. Sustainability 2011, 3, 2027-2049. [CrossRef]

20. McDowell, R.; Sharpley, A. Approximating phosphorus release from soils to surface runoff and subsurface drainage. J. Environ. Qual. 2001, 30, 508-520. [CrossRef]

21. Morrison, J.; Madramootoo, C.A.; Chikhaoui, M. Modeling the influence of tile drainage flow and tile spacin g on phosphorus losses from two agricultural fields in southern Quebec. Water Qual. Res. J. Can. 2013, 48, 279-293. [CrossRef]

22. Van der Salm, C.; Dupas, R.; Grant, R.; Heckrath, G.; Iversen, B.V.; Kronvang, B.; Levi, C.; Rubaek, G.H.; Schoumans, O.F. Predicting phosphorus losses with the PLEASE model on a local scale in Denmark and the Netherlands. J. Environ. Qual. 2011, 40, 1617-1626. [CrossRef] [PubMed]

23. Larsson, M.H.; Persson, K.; Ulen, B.; Lindsjo, A.; Jarvis, N. A dual porosity model to quantify phosphorus losses from macroporous soils. Ecol. Model. 2007, 205, 123-134. [CrossRef]

24. Šimůnek, J.; van Genuchten, M.T.; Šejna, M. Development and applications of the HYDRUS and STANMOD software packages and related codes. Vadose Zone J. 2008, 7, 587-600. [CrossRef] 
25. Kadyampakeni, D.M.; Nkedi-Kizza, P.; Morgan, K.T.; Schumann, A.W. Characterizing sorption and modeling phosphorus movement on Candler and Immokalee fine sand. J. Soil Water Sci. 2017, 1, 8-14. [CrossRef]

26. Ben-Gal, A.; Dudley, L.M. Phosphorus availability under continuous point source irrigation. Soil Sci. Soc. Am. J. 2003, 67, 1449-1456. [CrossRef]

27. Elmi, A.; Abou Nohra, J.S.; Madramootoo, C.A.; Hendershot, W. Estimating phosphorus leachability in reconstructed soil columns using HYDRUS-1D model. Environ. Earth Sci. 2011, 65, 1751-1758. [CrossRef]

28. Naseri, A.A.; Hoseini, Y.; Moazed, H.; Abbasi, F.; Samani, H.M.V.; Sakebi, S.A. Phosphorus Transport Through a Saturated Soil Column: Comparison Between Physical Modeling and HYDRUS-3D Outputs. J. Appl. Sci. 2011, 11, 815-823. [CrossRef]

29. Nakhaei, M.; Šimůnek, J. Parameter estimation of soil hydraulic and thermal property functions for unsaturated porous media using the HYDRUS-2D code. J. Hydrol. Hydromech. 2014, 62, 7-15. [CrossRef]

30. Hopmans, J.W.; Šimůnek, J.; Romano, N.; Durner, W. Inverse methods. In Methods of Soil Analysis. Part 4; SSSA Book Series, No. 5; Dane, J.H., Topp, G.C., Eds.; SSSA: Madison, WI, USA, 2002; pp. 963-1008. [CrossRef]

31. Filipović, V.; Weninger, T.; Filipović, L.; Schwen, A.; Bristow, K.L.; Zechmeister-Boltenstern, S.; Leitner, S. Inverse estimation of soil hydraulic properties and water repellency following artificially induced drought stress. J. Hydrol. Hydromech. 2018, 66, 170-180. [CrossRef]

32. Vrugt, J.A.; Stauffer, P.H.; Wöhling, T.; Robinson, B.A.; Vesselinov, V. Inverse modeling of subsurface flow and transport properties: A review with new developments. Vadose Zone J. 2008, 7, 843-864. [CrossRef]

33. Filipović, V.; Cambier, P.; Filipović, L.; Coquet, Y.; Pot, V.; Bodineau, G.; Jaulin, A.; Mercier, V.; Houot, S.; Benoit, P. Modeling Copper and Cadmium Mobility in an Albeluvisol Amended with Urban Waste Composts. Vadose Zone J. 2016, 15, 1-15. [CrossRef]

34. Filipović, V.; Coquet, Y.; Pot, V.; Houot, S.; Benoit, P. Modeling water and isoproturon dynamics in a soil profile with different urban waste compost application considering local heterogeneities. Geoderma 2016, 268, 29-40. [CrossRef]

35. IUSS Working Group WRB. World Reference Base for Soil Resources 2014. Update 2015: International Soil Classification System for Naming Soils and Creating Legends for Soil Maps; World Soil Resources Reports No. 106; FAO: Rome, Italy, 2015; p. 192.

36. Černe, M.; Palčić, I.; Pasković, I.; Major, N.; Romić, M.; Filipović, V.; Igrc, M.D.; Perčin, A.; Goreta Ban, S.; Zorko, B.; et al. The effect of stabilization on the utilization of municipal sewage sludge as a soil amendment. Waste Manag. 2019, 94, 27-38. [CrossRef]

37. Canet, R.; Pomares, F.; Cabot, B.; Chaves, C.; Ferrer, E.; Ribó, M.; Albiach, M.R. Composting of olive mill pomace and other residues from rural southeastern Spain. Waste Manag. 2008, 28, 2585-2592. [CrossRef]

38. EPA. U.S. Environmental Protection Agency. Method 1684; EPA: Washington, DC, USA, 2001.

39. Cornelissen, G.; Pandit, N.R.; Taylor, P.; Pandit, B.H.; Sparrevik, M.; Schmidt, H.P. Emissions and Char Quality of Flame-Curtain “Kon Tiki" Kilns for Farmer-Scale Charcoal/Biochar Production. PLoS ONE 2016, 11, e0154617. [CrossRef]

40. Gee, G.W.; Or, D. Particle-size analysis. In Methods of Soil Analysis. Part 4; SSSA Book Series, No. 5; Dane, J.H., Topp, G.C., Eds.; SSSA: Madison, WI, USA, 2002; pp. 1381-1402.

41. Schindler, U.; Durner, W.; von Unold, G.; Müller, L. Evaporation method for measuring unsaturated hydraulic properties of soils: Extending the measurement range. Soil Sci. Soc. Am. J. 2010, 74, 1071-1083. [CrossRef]

42. Vogel, T.; Císlerová, M. On the reliability of unsaturated hydraulic conductivity calculated from the moisture retention curve. Transp. Porous Med. 1988, 3, 1-15. [CrossRef]

43. Luckner, L.; van Genuchten, M.T.; Nielsen, D.R. A consistent set of parametric models for the two-phase flow of immiscible fluids in the subsurface. Water Resour. Res. 1989, 25, 2187-2193. [CrossRef]

44. Šimůnek, J.; Angulo-Jaramillo, R.; Schaap, M.G.; Vandervaere, J.P.; van Genuchten, M.T. Using an inverse method to estimate the hydraulic properties of crusted soils from tension disc infiltrometer data. Geoderma 1998, 86, 61-81. [CrossRef]

45. González, M.G.; Ramos, T.B.; Carlesso, R.; Paredes, P.; Petry, M.T.; Martins, J.D.; Aires, N.P.; Pereira, L.S. Modelling soil water dynamics of full and deficit drip irrigated maize cultivated under a rain shelter. Biosyst. Eng. 2015, 132, 1-18. [CrossRef] 
46. Šimůnek, J.; van Genuchten, M.T.; Šejna, M. Recent developments and applications of the HYDRUS computer software package. Vadose Zone J. 2016, 15, 25. [CrossRef]

47. Pote, D.H.; Daniel, T.C. Analyzing for Dissolved reactive phosphorus in water samples. In Methods of Phosphorus Analysis for Soils, Sediments, Residuals, and Waters; Pierzynski, G.M., Ed.; North Carolina State University: Raleigh, NC, USA, 2000; pp. 91-93.

48. Pote, D.H.; Daniel, T.C. Analyzing for total phosphorus and total dissolved phosphorus in water samples. In Methods of Phosphorus Analysis for Soils, Sediments, Residuals, and Waters; Pierzynski, G.M., Ed.; North Carolina State University: Raleigh, NC, USA, 2000; pp. 94-97.

49. Qiao, S.Y. Modeling Water Flow and Phosphorus Fate and Transport in a Tile Drained Clay Loam Soil Using HYDRUS 2D/3D. Master's Thesis, McGill University, Montreal, QC, Canada, 2014.

50. Marquardt, D.W. An algorithm for least-squares estimation of nonlinear parameters. J. Soc. Ind. Appl. Math. 1963, 11, 431-441. [CrossRef]

51. Hopmans, J.W.; Šimůnek, J. Review of inverse estimation of soil hydraulic properties. In Characterization and Measurement of the Hydraulic Properties of Unsaturated Porous Media; Van Genuchten, M.T., Leij, F.J., Wu, L., Eds.; University of California: Riverside, CA, USA, 1999; pp. 643-659.

52. Clausnitzer, V;; Hopmans, J.W. Non-Linear Parameter Estimation: LM_OPT. General-Purpose Optimization Code Based on the Levenberg-Marquardt Algorithm. Land, Air and Water Resources Paper; No. 100032; University of California: Davis, CA, USA, 1995.

53. Karbout, N.; Moussa, M.; Brahim, N.; Bol, R.; Bounina, H. Effect of Combined Application of Mineral Fertilizer in Soil Hydraulic Properties; Kallel, A., Ed.; Springer: Cham, Switzerland, 2018; pp. 269-272. [CrossRef]

54. Schneider, S.; Coquet, Y.; Vachier, P.; Labat, C.; Roger-Estrade, J.; Benoit, P.; Pot, V.; Houot, S. Effect of urban waste compost application on soil near-saturated hydraulic conductivity. J. Environ. Qual. 2009, 38, 772-781. [CrossRef] [PubMed]

55. Mohanty, B.P.; Bowman, R.S.; Hendrickx, J.M.H.; van Genuchten, M.T. New piecewise-continuous hydraulic functions for modeling preferential flow in an intermittent-flood-irrigated field. Water Resour. Res. 1997, 33, 2049-2063. [CrossRef]

56. Zhang, X.; Zhu, J.; Wendroth, O.; Matocha, C.; Edwards, D. Effect of Macroporosity on Pedotransfer Function Estimates at the Field Scale. Vadose Zone J. 2019, 18, 1-15. [CrossRef]

57. Vogeler, I.; Carrick, S.; Cichota, R.; Lilburne, L. Estimation of soil subsurface hydraulic conductivity based on inverse modelling and soil morphology. J. Hydrol. 2019, 574, 373-382. [CrossRef]

58. De Pinho, R.E.C.; de Miranda, J.H. Evaluation of HYDRUS-1D to simulate water and potassium transport in two laboratory tropical soil columns. Eng. Agric. Jaboticabal 2014, 34, 899-911. [CrossRef]

59. Muwamba, A.; Nkedi-Kizza, P.; Morgan, K.T. Determination of sorption coefficient of phosphorus applied for sugarcane production in southwestern Florida. J. Environ. Qual. 2016, 45, 1760-1768. [CrossRef]

60. Kadlec, R.H.; Knight, R.L. Treatment Wetlands, 2nd ed.; CRC Press: Boca Raton, FL, USA, 1996.

61. Grosse, W.; Wissing, F.; Perfler, R. Biotechnological Approach to Water Quality Improvement in Tropical and Subtropical Areas for Reuse and Rehabilitation of Aquatic Ecosystems; European Commission: Cologne, Germany, 1999.

62. Zhang, J.Z.; Huang, X.L. Relative importance of solid-phase phosphorus and iron on the sorption behavior of sediments. Environ. Sci. Technol. 2007, 41, 2789-2795. [CrossRef]

63. Iyamuremye, F.; Dick, R.P. Organic amendments and phosphorus sorption. Adv. Agron. 1996, 56, $139-185$. [CrossRef]

64. Guppy, C.N.; Menzies, N.W.; Moody, P.W.; Blamey, F.P.C. Competitive sorption reactions between phosphorus organic matter in soil: A review. Aust. J. Soil Res. 2005, 43, 189-202. [CrossRef]

65. Agbenin, J.O.; Igbokwe, S.O. Effect of soil- dung manure incubation on the solubility and retention of applied phosphate by a weathered tropical semi-arid soil. Geoderma 2006, 133, 191-203. [CrossRef]

66. Gichangi, E.M.; Mnkeni, P.N.S. Effects of goat manure and lime addition on phosphate sorption by two soils from the Transkei Region, South Africa. Commun. Soil Sci. Plan. 2009, 40, 3335-3347. [CrossRef]

67. Eduah, J.O.; Nartey, E.K.; Abekoe, M.K.; Henriksen, S.W.; Andersen, M.N. Mechanism of orthophosphate (PO4-P) adsorption onto different biochars. Environ. Technol. Innov. 2020, 17, 100572. [CrossRef] 
68. Zhu, X.M.; Chen, B.L.; Zhu, L.Z.; Xing, B.S. Effects and mechanisms of biocharmicrobe interactions in soil improvement and pollution remediation: A review. Environ. Pollut. 2017, 227, 98-115. [CrossRef]

69. Gondek, K.; Mierzwa-Hersztek, M.; Kopeć, M.; Sikora, J.; Głąb, T.; Szczurowska, K. Influence of biochar application on reduced acidification of sandy soil, increased cation exchange capacity, and the content of available forms of K, Mg, and P. Pol. J. Environ. Stud. 2019, 28, 1-9. [CrossRef]

(C) 2020 by the authors. Licensee MDPI, Basel, Switzerland. This article is an open access article distributed under the terms and conditions of the Creative Commons Attribution (CC BY) license (http://creativecommons.org/licenses/by/4.0/). 